\title{
Energy expenditure and physiological performance of Sudanese cane cutters
}

\author{
C. T. M. DAVIES, J. R. BROTHERHOOD, K. J. COLLINS, CAROLINE \\ DORÉ, F. IMMS, J. MUSGROVE, and J. S. WEINER \\ MRC Environmental Physiology Unit, London School of Hygiene and Tropical Medicine, \\ University of London, Keppel Street, London WC1E 7HT
}

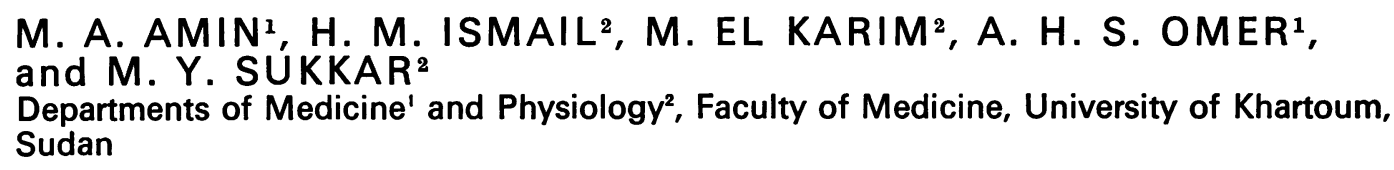

\begin{abstract}
Davies, C. T. M., Brotherhood, J. R., Collins, K. J., Doré, C., Imms, F., Musgrove, J., Weiner, J. S., Amin, M. A., Ismail, H. M., El Karim, M., Omer, A. H. S., and Sukkar, M. Y. (1976). British Journal of Industrial Medicine, 33, 181-186. Energy expenditure and physiological performance of Sudanese cane cutters. The thermal and exercise tolerances of 165 Sudanese cane cutters were measured in the laboratory and related to work performance and productivity in the cane fields. The results showed that the amount of cane cut per minute in the field was significantly correlated with changes in body weight $(r=+0.53)$ during the third hour of work, aerobic energy expenditure $(r=+0.43)$, and cardiac frequency during work. These variables in turn were associated with predicted maximal power output $\left(\mathrm{V}_{2}\right.$ max $)$ measured in the laboratory. The average energy expenditure during cane cutting was $1.66 \pm 0.331 / \mathrm{min}^{-1}\left(34.9 \mathrm{~kJ} / \mathrm{min}^{-1}\right)$ which represents approximately $60 \%$ of the workers predicted $\mathrm{V}_{2}$ max. This rate of energy expenditure was sustained in the cane fields for at least three hours without significant pauses for rest. The sweat losses measured in 32 cane cutters during the two and three hours of work averaged $637 \pm 221$ and $770 \pm$ $282 \mathrm{~g} / \mathrm{h}^{-1}$ respectively, while the mean urine temperature immediately on cessation of effort was $37.74 \pm 0.46^{\circ} \mathrm{C}$. Despite the additional environmental heat load of the tropics, it would seem that cane cutters performing a self-paced task demanding heavy physical effort, are able to sustain work levels well in excess of those recommended for most European factory workers without obvious signs of fatigue or heat stress.
\end{abstract}

There have been several studies on the energy expenditure and thermal tolerance of men working under laboratory conditions ( $\AA$ strand and Rodahl, 1970, for general review), in industry (Astrand, $1967 \mathrm{a}$ and b), and factories (Lehmann, Müller, and Spitzer, 1950; Christensen, 1953; Bink, 1962; Bonjer, 1962), mines (Lehmann et al., 1950; Garry et al., 1955; Wyndham et al., 1964), forests (Lundgren, 1946; Karvonen, 1958; Hansson, 1964) and in the armed forces (Edholm et al., 1955) where the work is controlled and to some extent regulated.

To our knowledge there are only a few studies of men performing self-paced activities. These are particularly relevant to developing countries where men often carry out heavy physical tasks with minimal supervision and mechanical assistance.

Heat and exercise tolerance has been examined by Ladell (1951) and by Ojikutu et al. (1972) in factory 
TABLE 1

Physical Characteristics of 165 Sudanese Cane Cutters

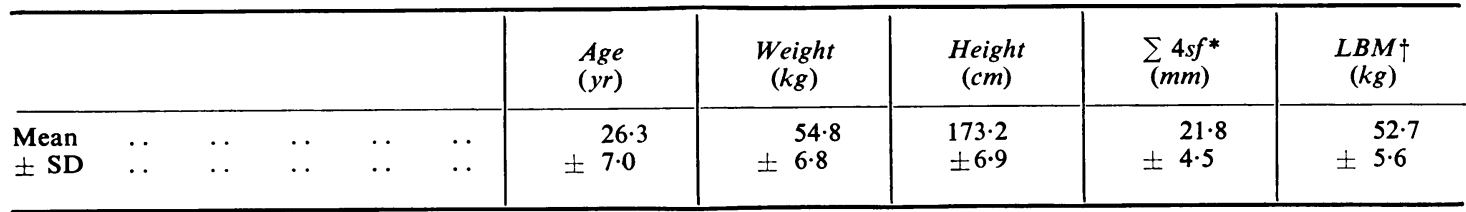

* Sum of four skinfold thicknesses;

tLean body mass (LBM) was calculated from skinfold thicknesses (Durnin and Rahaman, 1967)

workers in Nigeria, while Davies (1973) and Fenwick and Figenschou (1972) have examined the productivity of cane workers in East Africa, but no data were reported in these studies for the energy expenditure of physiological responses to the actual tasks performed by the men during their normal working days.

The present paper is concerned with studies on Sudanese cane cutters working on the Guneid Sugar Estate in the Gezira South of Khartoum, and examines the level of energy expenditure and productivity of workers in the cane fields in relation to their laboratory-measured exercise and thermal tolerance.

\section{Material}

The data were collected on 165 Sudanese cane cutters and form part of a larger study of the effects of schistosomiasis on work performance (Collins et al., 1976). The physical characteristics of the workers involved in the present investigation are shown in Table 1.

The subjects were required to attend the laboratory on one occasion only. They were initially habituated to exercise on the stationary bicycle ergometer and skinfold thicknesses, body height, and weight were measured. After these measurements had been taken they performed specific exercises and thermoregulatory function tests.

The exercise was in the form of a progressive test, the work load being raised every three minutes by 300 $\mathrm{kp} / \mathrm{min}^{-1}$ from zero load to the limit of the individual's work capacity. Minute ventilation, oxygen intake, and cardiac and respiratory frequencies were measured during the final minute of each work load. In each subject the oxygen intake $\left(\dot{\mathrm{V}}_{2}\right)$ at a work load of $900 \mathrm{kp} / \mathrm{min}^{-1}$ $\left(\dot{V}_{2}{ }_{200}\right)$, minute ventilation $\left(\dot{\mathrm{V}}_{\mathrm{E}}\right)$ at a carbon dioxide output $\left(\dot{\mathrm{V}}_{\mathrm{CO}}\right)$ of $1.5 \mathrm{l} / \mathrm{min}^{-1}\left(\dot{\mathrm{V}}_{\mathrm{E}_{1} \cdot 5}\right)$, tidal volume $\left(\mathrm{V}_{\mathrm{T}}\right)$ at a $\dot{\mathrm{V}}_{\mathrm{E}}$ of $30 \mathrm{1} / \mathrm{min}^{-1}\left(\mathrm{~V}_{\mathrm{T}_{30}}\right)$, cardiac frequency $\left(\dot{f}_{\mathrm{H}}\right)$ at a $\dot{\mathrm{V}} \mathrm{O}_{2}$ of $1.5 \mathrm{l} / \mathrm{min}^{-1}\left(\dot{\mathrm{f}}_{\mathrm{H}_{1.5}}\right)$, and $\dot{\mathrm{V}} \mathrm{O}_{2}$ at an $\dot{\mathrm{f}}$ of 195 beats $/ \mathrm{min}^{-1}\left(\mathrm{VO}_{2} \max\right.$ [predicted]) were estimated from the individual regression equations. Direct measurements of maximal aerobic power output $\left(\dot{\mathrm{V}}_{2}\right.$ max $)$ were not attempted.

Heat tolerance was measured on a thermoregulatory function test bed using the method described by Fox et al. (1967). The subjects voided their urine and were fitted with tympanic skin thermistors and dressed in sweat collecting suits. During the test tympanic temperature $\left(T_{t y}\right)$ was monitored from both ears, at two-minute intervals and skin temperature was recorded as the mean value from eight sites. The test was divided into three periods. After a short period of exposure to a neutral environment, the air temperature of the bed was lowered for 30 minutes and was then raised rapidly $\left(2^{\circ} \mathrm{C} \mathrm{min}{ }^{-1}\right)$ up to $45^{\circ} \mathrm{C}$ until the subject started sweating. The onset of sweating was detected by starch iodine papers held to the head for 30 seconds every two minutes. The air temperature of the bed was then raised to $55^{\circ} \mathrm{C}$ and maintained at this level until $\mathrm{T}_{\text {ty }}$ reached $37 \cdot 5^{\circ} \mathrm{C}$. The temperature of the bed was then progressively lowered to plateau the $\mathrm{T}_{\text {ty }}$ to $38^{\circ} \mathrm{C}$ and then maintained at this level for a 40-minute period of controlled hyperthermia. Sweat collection was made during the last 30 minutes of this period by applying suction to the suit; the sweat was then stored in universal containers for subsequent volume determination. The temperatures of sweat onset $\left(T_{\mathrm{so}}\right.$ ), and sweat rate (SR) during the period of controlled hyperthermia were used as indices of heat acclimatization. The rationale and theoretical basis of the method has been given in full by Fox et al. $(1967,1969)$.

Field productivity measurements were made on 129 of the subjects observed in the laboratory. Changes in body weight (to the nearest $50 \mathrm{~g}$ ) were recorded at hourly intervals using a portable beam balance set on a rigid platform. Heart rates were measured by palpation from the wrist. At the end of a three-hour period the weight of the cane cut by each man was measured. They did not urinate during the three-hour period of work, and any fluid intake was measured and accounted for in estimates of sweat loss. The temperature of voided urine was measured immediately on cessation of work as described by Fox et al. (1971). In 42 subjects direct measurements of oxygen intake were made over a 20 -minute period, using Kofranyi-Michaelis (KM) respirometers which were carried by the observers; expired gas was collected via a respiratory valve and $3.5 \mathrm{~m}$ length of flexible plastic tubing. This arrangement allowed the subject to work freely with a minimum of interference from the equipment and observer. The oxygen content of the expired air was measured on a portable paramagnetic oxygen analyser (Servomex Ltd) previously calibrated with gas mixtures of known concentration. Oxygen intake was determined from these measurements, and was converted to an energy expenditure value using the formula of Weir (1949) which ignores the expired $\mathrm{CO}_{2}$ content.

At hourly intervals during the period of study measurements of wet, dry, and globe temperatures were taken. These data together with the laboratory environmental temperature measurements are given in Table 2. A simple time and motion study was conducted on a small 
TABLE 2

Climatic Conditions in the Laboratory and the Cane Fields Mean Data for All the Days of Observation

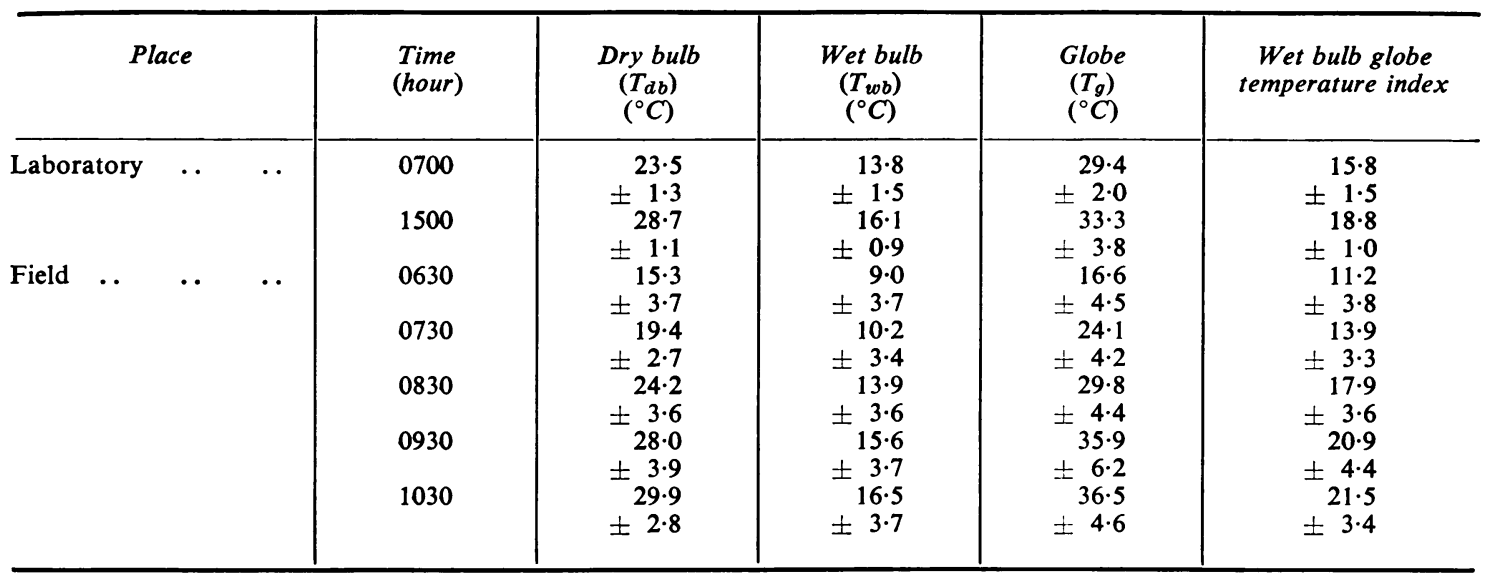

random sample of the subjects. The task of cane cutting was divided into four simple categories: cutting, stacking, walking, and resting and the time spent in these activities was recorded.

\section{Results}

The physiological responses to the exercise and thermoregulatory function tests are summarized in Table 3. There were no significant correlations between the indices $\left(\mathrm{T}_{\mathrm{so}}\right.$ and SR) of thermoregulatory function and the responses to exercise measured in the laboratory.

The rate of cane cut per working period was $15 \cdot 18 \pm 3.32 \mathrm{~kg} / \mathrm{min}^{-1}$. Productivity as measured in these terms was associated with the number of years' cane cutting experienced by the individual worker $(\mathrm{r}=+0.23 ; \mathrm{P}<0.01)$ and with predicted $\dot{\mathrm{VO}}_{2} \max$; the relationship was similar to that found in East African workers employed at the Kilombero sugar cane estate (Fig. 1).

The mean oxygen cost of cane cutting was $1.66 \pm$ 0.33 (range $0.85-2.41 ; \mathrm{n}=42 \mathrm{1} / \mathrm{min}^{-1}$ ). This is equivalent to an energy expenditure of $34.9 \pm 7 \cdot 0$ $\mathrm{kJ} / \mathrm{min}^{-1}$. The corresponding mean heart rate

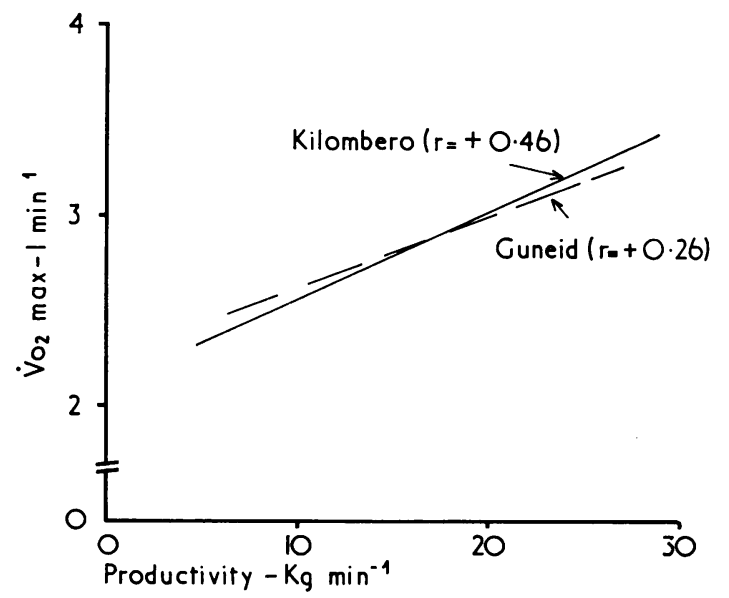

FIG. 1. The relationship between predicted $\dot{\mathrm{VO}}_{2 \max }$ and average productivity. Present (Sudan) data -... and previous data_ collected by Davies (1973) at the Kilombero Sugar Estate, Tanzania, East Africa

during the period of the $K_{m}$ measurements was $139 \pm 18$ beats $/ \mathrm{min}^{-1}$. This compared with a mean

TABLE 3

Response to Submaximal Exercise (Bicycle) and Thermoregulatory Function (Bed) Tests $(\mathbf{n}=165$ )

\begin{tabular}{|c|c|c|c|c|c|c|c|c|c|}
\hline \multicolumn{6}{|c|}{ Test } & Variable & Units & Mean & $S D$ \\
\hline Bicycle & $\cdots$ & .. & . & .. & . & $\begin{array}{l}\dot{V}_{2900} \\
\dot{V}_{E_{1 \cdot 5}} \\
V_{T_{30}} \\
\dot{f}_{H} \cdot 5 \\
\dot{V}_{1 \cdot 5} O_{22 x} \text { (predicted) } \\
T_{S O} \\
\text { SR }\end{array}$ & $\begin{array}{c}1 / \min ^{-1} \text { STPD } \\
1 / \min ^{-1} \text { BTPS } \\
\text { I BTPS } \\
\text { beats/min } \\
\text { 1/min }{ }^{-1} \text { STPD } \\
{ }^{\circ} \mathrm{C} \\
\quad \mathrm{ml}^{-1} \mathrm{~h}^{-1}\end{array}$ & $\begin{array}{c}2 \cdot 19 \\
47 \cdot 24 \\
1 \cdot 97 \\
126 \\
2 \cdot 87 \\
36 \cdot 88 \\
339\end{array}$ & $\begin{array}{l} \pm \quad 0 \cdot 18 \\
\pm \quad 9 \cdot 31 \\
\pm \quad 0 \cdot 24 \\
\pm \quad 18 \\
\pm \quad 0 \cdot 49 \\
\pm \quad 0 \cdot 33 \\
\pm 172\end{array}$ \\
\hline
\end{tabular}


figure of $135 \pm 15$ beats $/ \mathrm{min}^{-1}$, found during other periods of time when the cane cutters were not being measured with the $K_{m}$ (Table 4). The energy cost of cane cutting was positively associated with the weight of cane cut per minute, $(r=+0.43$, $P<0.001$ ). The mean oxygen intake in the field corresponded to $59 \pm 14 \%$ of the predicted $\mathrm{V}_{2} \max$ measured in the laboratory. During the three-hour period of cane cutting, the workers generally spent $91 \%$ of their time either cutting or stacking, only $5 \%$ in walking, and less than $2 \%$ resting.

TABLE 4

Indices of Physiological Performance Measured IN THE FIELD

\begin{tabular}{l|r|c}
\hline \multicolumn{1}{c|}{ Variable } & Mean & \multicolumn{1}{c}{$S D$} \\
\hline Seasons experience $\ldots$ & $3 \cdot 07$ & $\pm 2 \cdot 52$ \\
Productivity (cane cut) $\left(\mathrm{kg} / \mathrm{min}^{-1}\right)$ & $15 \cdot 18$ & $\pm 3 \cdot 32$ \\
Energy expenditure $\left(1 / \mathrm{min}^{-1}\right)$ & $1 \cdot 66$ & $\pm 0 \cdot 33$ \\
Cardiac frequency $\left(\mathrm{beats} / \mathrm{min}^{-1}\right) .$. & 139 & \pm 18 \\
Relative work level $\left(\% \dot{V}_{2} \max \right) .$. & 59 & \pm 14 \\
Change of weight $(\mathrm{g} / \mathrm{second}$ hour) & 637 & \pm 221 \\
Change of weight $(\mathrm{g} /$ third hour) & 770 & \pm 282 \\
\hline
\end{tabular}

The mean weight changes of 32 cane cutters during the second and third hours of work, were $637 \pm 221$ and $770 \pm 282 \mathrm{~g}$ respectively. The change in weight during the third hour of work was positively associated with predicted $\mathrm{V}_{2} \max (\mathrm{r}=+0.34$, $P<0.05)$ and average productivity $(r=+0.53$, $P<0.01)$. The maximal sweat rate attained in the field was correlated $(r=0.52, P<0.001)$ with the sweat loss measured in the laboratory bed test at a constant body temperature of $38^{\circ} \mathrm{C}$ (Fig. 2).

At the end of the work period the average temperature of urine from 26 cane cutters was $37.74 \pm$ $0.46^{\circ} \mathrm{C}$. This was $1.0-1 \cdot 5^{\circ} \mathrm{C}$ higher than the mouth temperature recorded during the same period of time.

\section{Discussion}

The present data were collected during an investigation of the effects of schistosomiasis on work performance (Collins et al., 1976). An analysis of the effects of schistosomiasis on the variance of the physiological variables presented here showed that no significant differences existed between those workers who had the disease and those in whom it was absent. In this paper, therefore, those workers who were measured both in the laboratory and in the cane fields have been treated as a homogeneous group. The responses to submaximal exercise and predicted $\mathrm{VO}_{2} \max$ accord with previous observations collected on African workers engaged in heavy

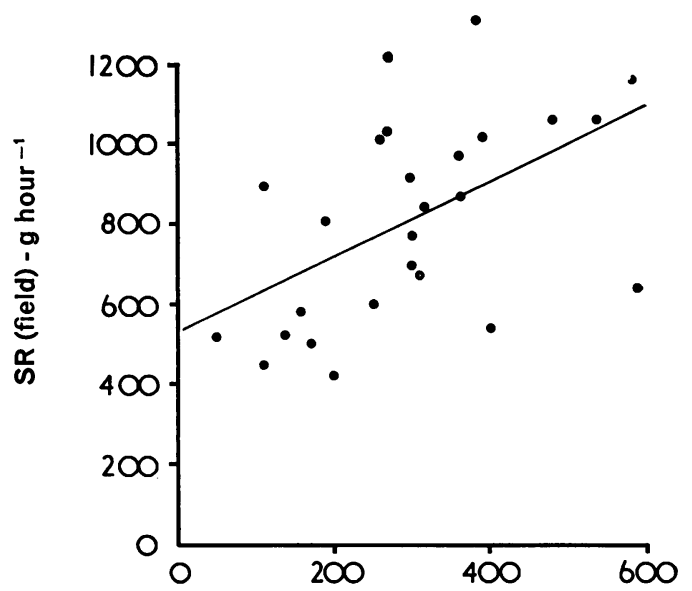

SR (bed) - g hour ${ }^{-1}$

FIG. 2. Relationship between maximal sweat rate in the field, SR (field) and sweat loss in thermoregulatory function bed test measured at $38^{\circ} \mathrm{C}$ in the laboratory, SR (bed)

$$
\begin{aligned}
\mathrm{Y}(\mathrm{SR} \text { field }) & =541.5+0.91(\mathrm{SR} \text { bed }) \\
\mathrm{Y} & =0.52, \mathrm{P}<0.001
\end{aligned}
$$

physical tasks (Ojikutu et al., 1972; Davies, 1973); the levels of energy expenditure during cane cutting are also comparable to those found recently by Spurr, Barac-Nieto, and Maksud (1974). A mean aerobic energy output value of $34.9 \mathrm{~kJ} / \mathrm{min}^{-1}$ is within the range found for coal mining and corresponds to the work rate voluntarily chosen by lumberjacks when felling trees (Passmore and Durnin, 1955). Thus despite their relatively low predicted $\mathrm{VO}_{2 \max }$ in European terms (Davies, 1968; Davies et al., 1972) the cane cutters are able to maintain a work rate equivalent to $59 \%$ of their estimated maximal work performance. This is certainly a higher figure than that recorded by Bink (1962) for industrial workers, and by Bonjer (1962) and Åstrand (1967b) for building workers. However some caution is necessary in interpreting the present results. The maximal performance was predicted from the responses to submaximal exercise during upright exercise on a bicycle ergometer; it has previously been shown (Davies, 1968) that $\dot{V}_{2 \max }$ predicted in this way may underestimate true maximal performance, and may give rise to a serious overestimate of the relative work load as calculated in the present study. It is impossible to reproduce the work of cane cutting, which is mainly confined to the trunk, shoulders and arms, by exercise on the bicycle ergometer. However, several workers (Asmussen and Hemmingsen, 1958; Åstrand and Saltin, 1961) have shown that the $\mathrm{VO}_{2 \max }$ of unrestricted work with arms and upper body is lower than upright bicycle work with the legs and this factor may have the opposite effect on the calcula- 
tion of relative work load in cane cutting, thus offsetting the error of overestimation given above. In addition, one cannot assess the effect of the presence of an observer on the energy expenditure of the worker in the cane fields. Undoubtedly, some workers tend to work harder if they feel they are being watched and this may have contributed to the relatively high measurements of $\mathrm{VO}_{2}$ obtained with the $K_{m}$ in the field. On the other hand, cardiac frequency (139 \pm 18 beats/min $\left.{ }^{-1}\right)$ recorded during the wearing of the $K_{m}$ respirometer was similar to the value $\left(135 \pm 15\right.$ beats $\left./ \mathrm{min}^{-1}\right)$ found in other cane cutters measured at random in the fields. It may well be that our calculated figure of $59 \%$ V $\mathrm{O}_{2 \max }$ is too high, so that the relative work load which the cane cutter may be able to sustain is nearer $50 \%$. If we accept the finding that urine temperatures (Fox, personal communication) consistently underestimate rectal temperature by $0 \cdot 2-0 \cdot 3^{\circ} \mathrm{C}$ then our mean urine temperature of $37.74^{\circ} \mathrm{C}$ would support this conclusion (Saltin and Hermansen, 1966). On balance one can conclude that cane cutters performing selfpaced work in hot conditions are capable of sustaining work levels in excess of those reported for most European workers and, more importantly, without significant pauses for rest. During observation in the cane fields the cutters spent less than $2 \%$ of their time not obviously engaged in activity. This is quite contrary to the observations made in the armed forces (Edholm et al., 1955), and in the building industry ( $\AA$ strand, 1967b). Åstrand found that workers involved in manual labour who were able to set their own pace, adopted a work rate of $40 \%$ of their $\mathrm{VO}_{2 \text { max, }}$ frequently alternating rest and work periods. However, our observations are similar to those of Hansson (1964) who found that lumberjacks rarely took long breaks and preferred to work at an even rate throughout the day.

The productivity in the fields was related to the individuals $\dot{\mathrm{VO}}_{2 \max }$ (Fig. 1). This confirms the observations of Davies (1973) on a similar group of subjects in East Africa and finds support in the results of Hansson (1964) who found that lumberjacks with large earnings were invariably characterized by high aerobic power output. During their period of work the cutters on average lost $3 \%$ of their body weight and were sweating profusely during the third hour of work. The change in weight during this period was highly correlated with energy expended, the amount of cane cut, cardiac frequency, the individual's predicted $\dot{\mathrm{V}} \mathrm{O}_{2 \max }$, and the sweat loss measured in the controlled hyperthermia bed test (Fig. 2). These observations underline the importance of an individual's heat and exercise tolerance to his capacity to sustain prolonged hard physical work in the hot environment of the tropics. The Sudanese sugar cane worker is able to sustain a level of work in excess of that recommended for most industrialized countries without undue sign of fatigue or heat stress.

\section{References}

Asmussen, E. and Hemmingsen, I. (1958). Determination of maximum working capacity at different ages in work with the legs or with arms. Scandinavian Journal of Clinical and Laboratory Investigation, 10, 67-71.

Åstrand, I. (1967a). Aerobic work capacity in men and women in some professions. Försvarsmedicin, 3, 163. (1967b). Degree of strain during building work as related to individual aerobic work capacity. Ergonomics, 10, 293.

Åstrand, P.-O. and Rodahl, K. (1970). Textbook of Work Physiology. McGraw-Hill, New York.

- and Saltin, B. (1961). Maximal $\mathrm{O}_{2}$ uptake and heart rate in various types of physical activity. Journal of Applied Physiology, 16, 977.

Bink, B. (1962). The physical working capacity in relation to working time and age. Ergonomics, 5, 25-28.

Bonjer, F. H. (1962). Actual energy expenditure in relation to working capacity. Ergonomics, 5, 29-31.

Christensen, E. H. (1953). Physiological valuation of work in the Nykoppa iron works. In Fatigue, edited by W. F. Floyd and A. T. Welford. Lewis, London.

Collins, K. J., Brotherhood, J. R., Davies, C. T. M., Doré, C., Hackett, J., Imms, F., Musgrove, J., Weiner, J. S., Amin, M. A., Karim, M. E. L., Ismail, H. M., Omer, A. H. S., and Sukkar, M. Y. (1976). Physical performance and work capacity of Sudanese cane cutters with Schistosoma mansoni infection. American Journal of Tropical Medicine and Hygiene, 25,410-421.

Davies, C. T. M. (1968). Limitations to the prediction of maximum oxygen intake from cardiac frequency measurements. Journal of Applied Physiology, 24, 700-706.

- (1973). Relation of maximum aerobic power to productivity and absenteeism of East African sugar cane workers. British Journal of Industrial Medicine, 30, 146-154.

- Barnes, C. A., Fox, R. H., Ojikutu, R. O., and Samueloff, A. S. (1972). Ethnic difference in physical work capacity. Journal of Applied Physiology, 33, 726-732.

Durnin, J. V. G. A. and Rahaman, M. M. (1967). The assessment of the amount of fat in the human body from measurements of skinfold thickness. British Journal of Nutrition, 21, 681-689.

Edholm, O. G., Fletcher, J. G., Widdowson, E. M., and McCance, R. A. (1955). Energy expenditure and food intake of individual men. British Journal of Nutrition, 9, 286-300.

Fenwick, A. and Figenschou, B. H. (1972). The effect of Schistosoma mansoni infection on the productivity of cane cutters on a sugar estate in Tanzania. Bulletin of the World Health Organization, 47, 567-572.

Fox, R. H., Crockford, G. W., Hampton, I. F. G., and MacGibbon, R. (1967). A thermoregulatory function test using controlled hyperthermia. Journal of Applied Physiology, 23, 267-275.

- Lofstedt, B., Woodward, P. M., Eriksson, E., and 
Werkstrom, B. (1969). Comparison of thermoregulatory function in men and women. Journal of Applied Physiology, 26, 444-453.

, Woodward, P. M., Fry, A. J., Collins, J. C., MacDonald, I. C. (1971). Diagnosis of accidental hypothermia of the elderly. Lancet, 1, 424-427.

Garry, R. C., Passmore, R., Warnock, G. M., and Durnin, J. V. G. A. (1955). Expenditure of energy and consumption of food by miners and clerks, Fife, Scotland. Medical Research Council Special Report Series, No. 289. HMSO, London.

Hansson, J. E. (1964). The relationship between individual characteristics of the workers and output of work in logging operations. In Proceedings of the 2 nd International Ergonomics Association Congress, Dortmund, pp. 113-120.

Karvonen, M. J. (1958). Use of competitive tests as a method of performance research. Ergonomics, 1 , 137-150.

Ladell, W. S. S. (1951). Inherent acclimatization of indigenous West Africans. Journal of Physiology, 112, $15 \mathrm{P}$.

Lehmann, G., Müller, E. A., and Spitzer, H. (1950). Der Calorienbedarf bei gewerblicher Arbeit. Arbeitsphysiologie, 14, 166.

Lundgren, N. (1946). Physiological effects of time schedule work on lumber workers. Acta Physiologica Scandinavica, 13, Suppl. 41.
Ojikutu, R. O., Fox, R. H., Davies, C. T. M., and Davies, T. W. (1972). Heat and exercise tolerance of rural and urban groups in Nigeria. In Human Biology of Environmental Change, edited by D. J. M. Vorster, pp. 132-144. International Biological Programme, London.

Passmore, R. and Durnin, J. V. G. A. (1955). Human energy expenditure. Physiological Reviews, 35, 801-840.

Saltin, B. and Hermansen, L. (1966). Esophageal, rectal and muscle temperature during exercise. Journal of Applied Phvsiology, 21, 1757.

Spurr, G. B., Barac-Nieto, M., and Maksud, M. G. (1974). Relationships among productivity aerobic power and energy cost in heavy physical labour. In Proceedings of XXVI International Congress of Physiology, Vol. XI, p. 274.

Weir, J. E. de V. (1949). New methods for calculating metabolic rate with special reference to protein metabolism. Journal of Physiology, 109, 1-9.

Wyndham, C. H., Cooke, H. M., Munro, A., and Maritz, J. S. (1964). The contribution of physiological factors to the performance of moderately heavy physical work. Ergonomics, 7, 121-137.

Received for publication 31 October 1975 Accepted for publication 23 January 1976 